Article

\title{
Glacier Changes in the Semi-Arid Huasco Valley, Chile, between 1986 and 2016
}

\author{
Katharina Hess ${ }^{1, *}$, Susanne Schmidt ${ }^{2, * \mathbb{D}}$, Marcus Nüsser ${ }^{1,2} \mathbb{D}$, Carina Zang ${ }^{1}$ and \\ Juliane Dame ${ }^{1,2}$ \\ 1 Heidelberg Center for the Environment (HCE), Heidelberg University, 69120 Heidelberg, Germany; \\ marcus.nuesser@uni-heidelberg.de (M.N.); zang.carina@uni-heidelberg.de (C.Z.); \\ Juliane.Dame@uni-heidelberg.de (J.D.) \\ 2 Department of Geography, South Asia Institute (SAI), Heidelberg University, 69115 Heidelberg, Germany \\ * Correspondence: K.Hess@stud.uni-heidelberg.de (K.H.); s.schmidt@uni-heidelberg.de (S.S.); \\ Tel.: +49-(0)6221-54-15240 (S.S.)
}

Received: 30 July 2020; Accepted: 26 October 2020; Published: 29 October 2020

\begin{abstract}
In the semi-arid and arid regions of the Chilean Andes, meltwater from the cryosphere is a key resource for the local economy and population. In this setting, climate change and economic activities foster water scarcity and resource conflicts. The study presents a detailed glacier and rock glacier inventory for the Huasco valley $\left(28-29^{\circ} \mathrm{S}\right)$ in northern Chile based on a multi-temporal remote sensing approach. The results indicate a glacier-covered area of $16.35 \pm 3.06 \mathrm{~km}^{2}(\mathrm{n}=167)$ and, additionally, 50 rock glaciers covering an area of about $8.6 \mathrm{~km}^{2}$ in 2016 . About $81 \%$ of the ice-bodies are smaller than $0.1 \mathrm{~km}^{2}$, and only four glaciers are larger than $1 \mathrm{~km}^{2}$. The change analysis reveals a more or less stable period between 1986 and 2000 and a drastic decline in the glacier-covered area by about 35\% between 2000 and 2016. The detailed assessment of six subregions indicates a more pronounced glacier decrease in the vicinity of the Pascua Lama mining project.
\end{abstract}

Keywords: glacier change; Chilean Andes; water resources; Pascua Lama; Norte Chico

\section{Introduction}

Mountain glaciers play an essential role as water resources in arid and semi-arid regions [1-3]. In the case of Chile, glacial meltwater is crucial for more than $70 \%$ of the population $[4,5]$. While Andean glaciers are severely affected by climate change, those in the semi-arid North-Central Chile have received less attention [6]. Likewise, the regional importance of rock glaciers for water storage becomes increasingly evident [7-9]. Declining precipitation and aridification in northern Chile over the 20th century [10] cannot solely be drawn back to El Niño Southern Oscillations (ENSO) variability. Rather, sea surface temperature change from the South Pacific Amundson Sea region has influenced the winter storm tracks in North-Central Chile [11]. Average temperatures rose by $1-2{ }^{\circ} \mathrm{C}$ during the 20th century $[12,13]$ and will continue to rise in the future with longer periods of snow and glacier melt [13]. The 2019 IPCC (Intergovernmental Panel on Climate Change) special report on the Ocean and Cryosphere in a Changing Climate (SROCC) predicts that the Andean cryosphere continues to decrease, and small glaciers will disappear towards the end of the century [1]. The water stored in the glaciers of North-Central Chile determines the potential for irrigated agriculture [14]. Snow and ice melt are indispensable for regular water availability, especially in years with low or zero summer precipitation $[15,16]$. It is, therefore, important to precisely quantify current glacier areas and changes to them to estimate the remaining water stored in the cryosphere [15]. The reduction in annual runoff may exacerbate conflicts between different water users [6], such as agricultural producers, mining companies, and local communities. The case study of the Huasco valley has witnessed conflicts over 
water governance ever since the Pascua Lama gold mine in the upper valley section became a focus of resistance for the controversial extraction of mineral resources in the Andean Main Cordillera and faced increasing media scrutiny [16-18]. Environmental impacts of mining activities on glaciers and regional water availability have been in the foreground in this conflict.

Cryosphere studies are limited due to poor accessibility and the rough environment of the main Andean range $[17,19]$. A first glacier inventory for northern Chile $\left(18-32^{\circ} \mathrm{S}\right)$ was implemented by Garín using aerial photographs from 1955 and 1961 [20]. By the end of the last century, Rivera et al. [21] noticed a significant glacier retreat in Chile that was higher than in other parts of the world [21,22]. According to them, the Los Tronquitos glacier $\left(28^{\circ} 32^{\prime} \mathrm{S}, 69^{\circ} 43^{\prime} \mathrm{W}\right)$, one of the largest glaciers in northern Chile [8,20] and close to the Huasco valley, lost $11.4 \%\left(0.52 \mathrm{~km}^{2}\right)$ of its area between $1955-1985$ [22]. According to Rabatel et al. [23], who investigated the changes in mass balance and glacier-covered area in the vicinity of the Pascua Lama Mine $\left(29^{\circ} 19^{\prime} \mathrm{S}, 70^{\circ} 01^{\prime} \mathrm{W}\right)$, the glacier-covered area has shrunk by 29\% between 1955 and 2007 [23].

A first combined glacier and rock glacier inventory of the complete Huasco valley was presented by Barcaza et al. [24], who documented 334 ice-bodies covering an area of $32.6 \mathrm{~km}^{2}$ in 2003 [24]. Nicholson et al. [8] mapped 111 glaciers and glacierets with a total area of $16.86 \mathrm{~km}^{2}$ and 40 active rock glaciers with a total area of $6.30 \mathrm{~km}^{2}$ using ASTER satellite data from February 2004. Brenning and Azócar [25] identified 424 active rock glaciers covering an area of $23.5 \mathrm{~km}^{2}$, which were derived from aerial photos taken between 1996 and 2000. This inventory was used for a permafrost distribution model to predict the occurrence of rock glaciers for the semi-arid Chilean Andes (28.5-32.2 $\left.{ }^{\circ} \mathrm{S}\right)$ [26]. The majority of permafrost related studies, however, concentrate on the central Chilean Andes close to the capital Santiago de Chile $[7,12,27,28]$.

Comparative change detection studies of glaciers across the Huasco catchment are largely absent, despite the controversial impact of mining and construction activities. Previous studies [8,19-23,25] have highlighted the need for further glaciological long-term monitoring in the region. However, several mass balance studies have been carried out at Guanaco Glacier and Pascua Lama [23,29,30], without considering the impact of an anthropogenic increase in dust deposits on glaciers.

The aims of the present study are (i) to map glaciers and rock glaciers of the Huasco valley; (ii) to analyze their regional distribution and their relationship to topographical variables; (iii) to detect glacier changes between 1986, 2000 and 2016, and (iv) to estimate the impact of mining infrastructure on glacier decrease.

\section{Study Area}

The upper Huasco valley $\left(28^{\circ} 53^{\prime} \mathrm{S}, 69^{\circ} 56^{\prime} \mathrm{W}\right.$ to $\left.29^{\circ} 33^{\prime} \mathrm{S}, 70^{\circ} 11^{\prime} \mathrm{W}\right)$ is located in the Atacama Region (Region III) in North-Central Chile. The watershed stretches from the western Cordillera of the Andes, which marks the border to Argentina in the East, to the Pacific Ocean in the West (Figure 1). The two main tributaries El Tránsito in the north and El Carmen in the south, covering together an area of about $7100 \mathrm{~km}^{2}$, confluence to the Huasco river near the town of Alto del Carmen [19,31,32].

The altitude of the upper Huasco valley ranges from $782 \mathrm{~m}$ (all elevations in this study are given in above sea level) in the lowermost section in the west to the highest peak of about $6150 \mathrm{~m}$ in the east. The median elevation of the Tránsito and Carmen watershed is $3497 \mathrm{~m}$ and $3642 \mathrm{~m}$, respectively.

Most ice-bodies in this semi-arid mountain environment are very small $\left(<0.25 \mathrm{~km}^{2}\right)$ and have been referred to as glacierets, cryospheric forms that originate from perennial snow cover in sheltered positions, often nourished by avalanches or wind-driven snow accumulation with little or no detectable ice-flow pattern at the surface $[8,23]$. The extrapolated $0{ }^{\circ} \mathrm{C}$ isotherm of mean annual air temperature is located at an altitude of about $4350 \mathrm{~m}$ [25]; thus, a distinct separation of glacial accumulation and ablation zones does not exist. Similar to tropical glaciers, ablation occurs across the entire glacier $[23,30]$. All glaciers in the region show low viscosity and are considered cold glaciers [19,21,23]. High solar radiation and strong winds result in high sublimation rates $[19,33,34]$. 


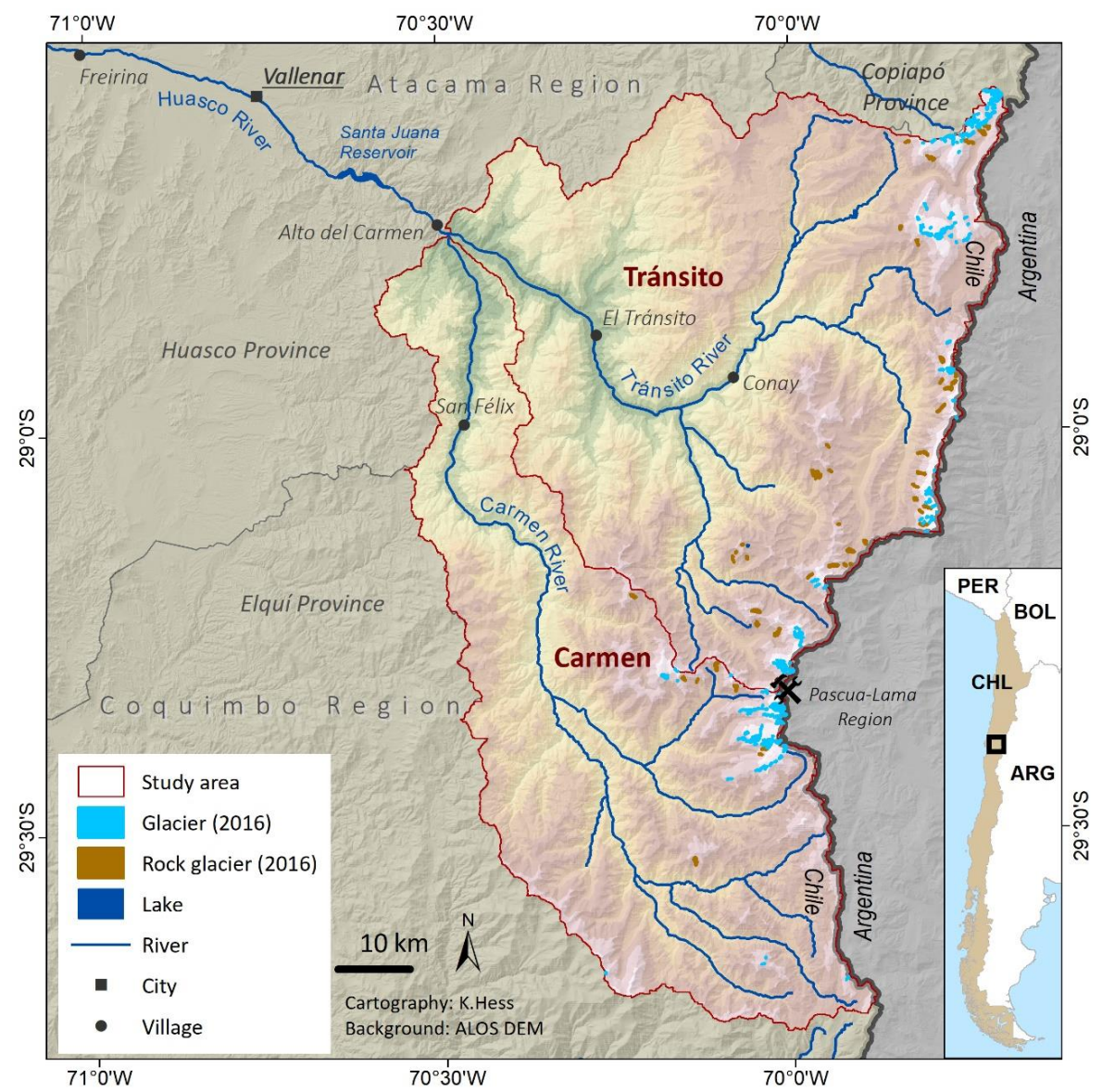

Figure 1. Map of the Upper Huasco Valley.

The Huasco valley is located south of the prominent South American Arid Diagonal, which crosses the Andes between $25-27^{\circ} \mathrm{S}[23,35]$ and forms a transition zone between tropical and subtropical circulations on the one hand and the westerlies on the other. Both circulation systems are characterized by distinct seasonality and blocked by the Pacific anticyclone, resulting in pronounced aridity along the diagonal zone [32]. The Huasco valley is predominantly influenced by the westerly circulation, with $81-85 \%$ of the annual precipitation occurring during the austral winter between May and August [32,33,36] and episodic easterly precipitation in summer [19]. The characteristic high interannual climatic variability in the area is reinforced by ENSO with wetter winter conditions every 3-6 years, providing years with higher snow accumulation $[19,32,37]$. Drier La Niña events are regularly associated with less winter precipitation and stronger ablation. The last El Niño year occurred in 2015 with heavy precipitation and flooding in the Huasco watershed [31,32].

The population in the upper Huasco valley increased from 4840 to about 5300 inhabitants between 2002 and 2017, who live in dispersed rural settlements with a population density of just 0.9 persons per $\mathrm{km}^{2}$ [38]. The main source of income is irrigated agriculture along the riverbed, with table grapes, avocados, and grapes for viniculture (Figure 2) as main crops [39]. Between 2009 and 2013, employment in the agricultural sector increased from $52 \%$ to $68 \%$ [38]. Population growth and steadily expanding irrigation by export-oriented agricultural companies contribute to rising water demand [40].

The upper Huasco valley became prominent due to the conflict over the construction of the Pascua Lama open-pit mine at the Argentine-Chilean border [16-18,41] (Figure 3). The Canadian company Barrick Gold planned to mine one of the largest remaining gold deposits in the headwaters of the Huasco valley at altitudes between 4400 and $5300 \mathrm{~m}$ [18,42]. The project gained international attention when the first environmental impact assessment (EIA), approved in 2001 [43], including the plan to relocate 10 ha of the ice-covered area as the gold is located underneath the three glaciers Toro 1 , 
Toro 2, and Esperanza [18,41,42,44,45]. After a second, revised EIA in the context of Barrick's plans to expand the project in 2004, public resistance increased significantly [16-18,41,46]. Nevertheless, mining construction started in 2009, while exploration work accompanied by road construction had already begun in the mid-1990s [41] and is detectable on satellite imagery. Protests against the mine led to a temporary halt in 2013 [47,48]. In 2018, Chile's environmental tribunal shut down the project [43].

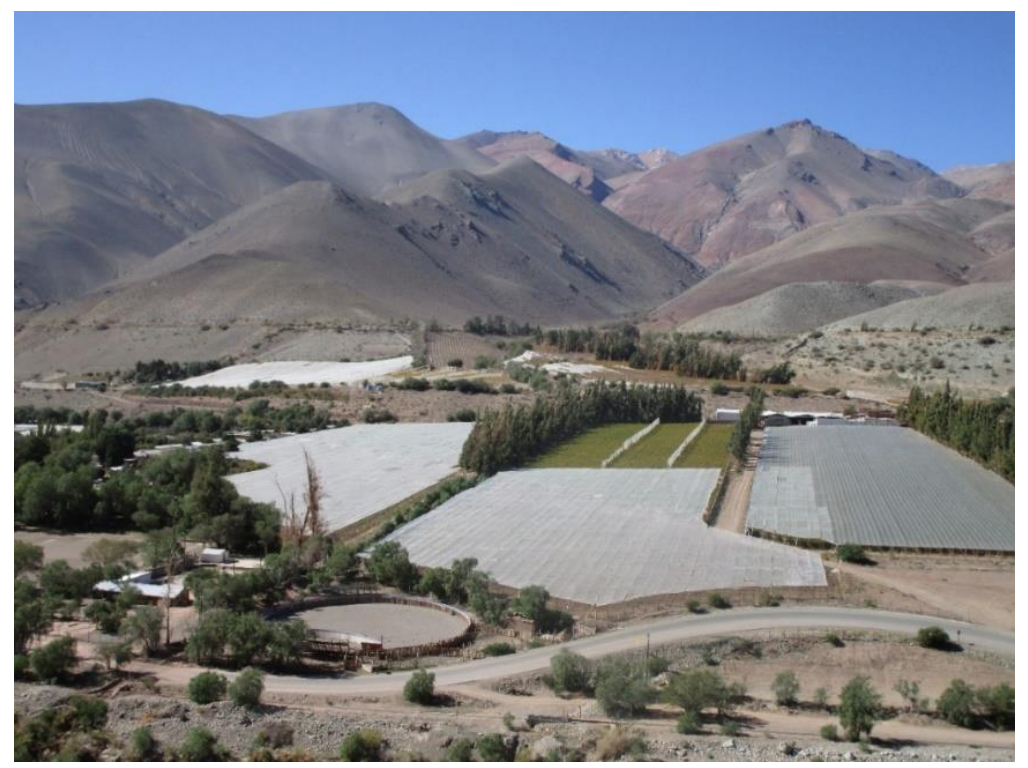

Figure 2. Table grape plantations near the town of El Tránsito (picture: C. Zang, May 2015).

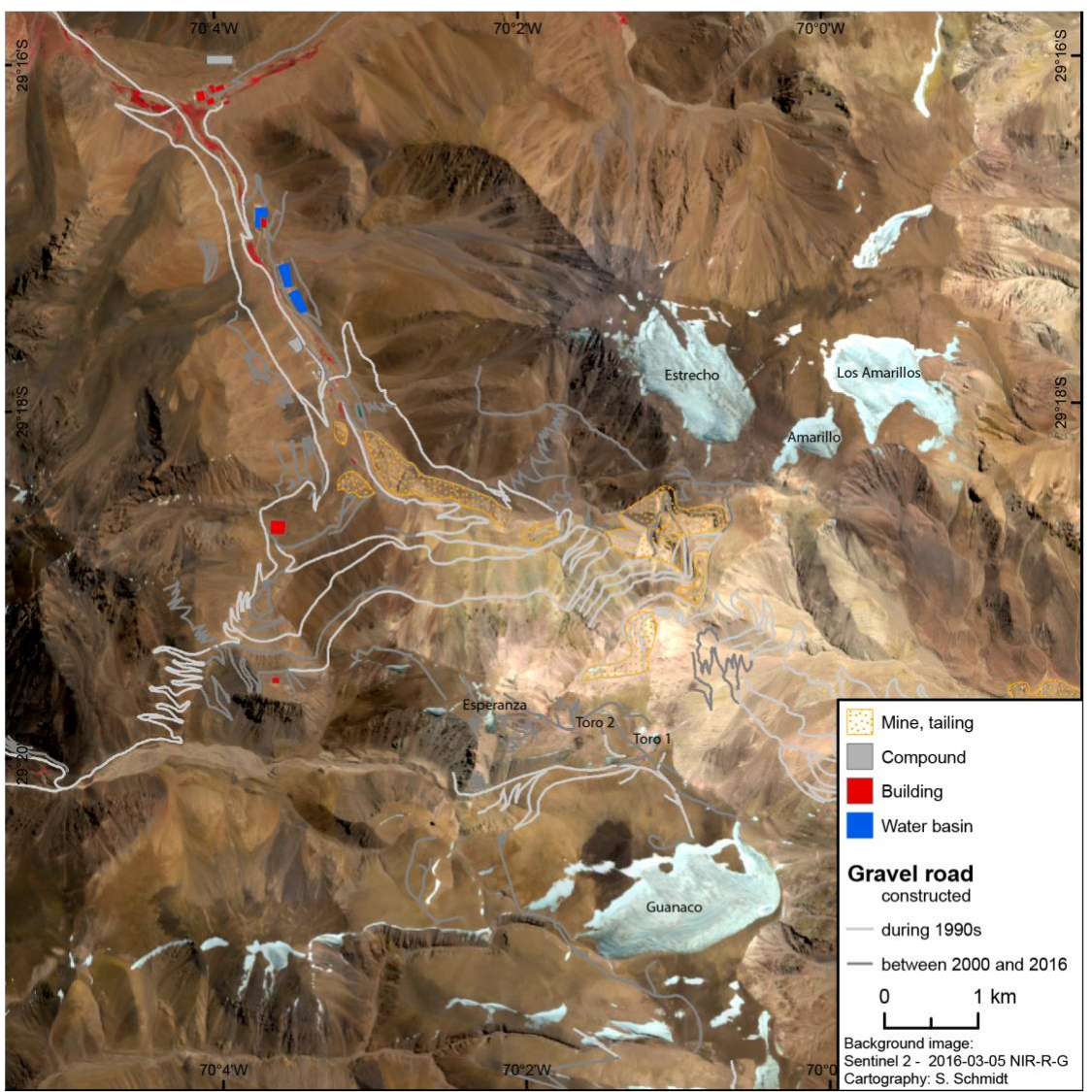

Figure 3. Road construction and mining in Pascua Lama. 


\section{Materials and Methods}

\subsection{Data Selection and Preprocessing}

Multispectral satellite imagery was used to map glaciers and rock glaciers. To minimize the impact of seasonal snow cover, images at the end of the ablation period and before the first snowfall event were considered optimal for glacier detection [49-51]. A Sentinel-2A scene from 5 March 2016, provided by ESA (European Space Agency), was found to be suitable for the glacier inventory (Table 1).

Since Sentinel-2A was launched in June 2015 [52], Landsat-5 imagery from 31 March 1986, and Landsat-7 data from 31 March 2000, were used for glacier change detection. Similar dates were selected to minimize seasonal shading effects [53]. The radiometrically calibrated Landsat and Sentinel-2 scenes were mosaicked and resized to the study area. All preprocessing steps and classifications were carried out in ENVI 4.8.1 (Figure 4).

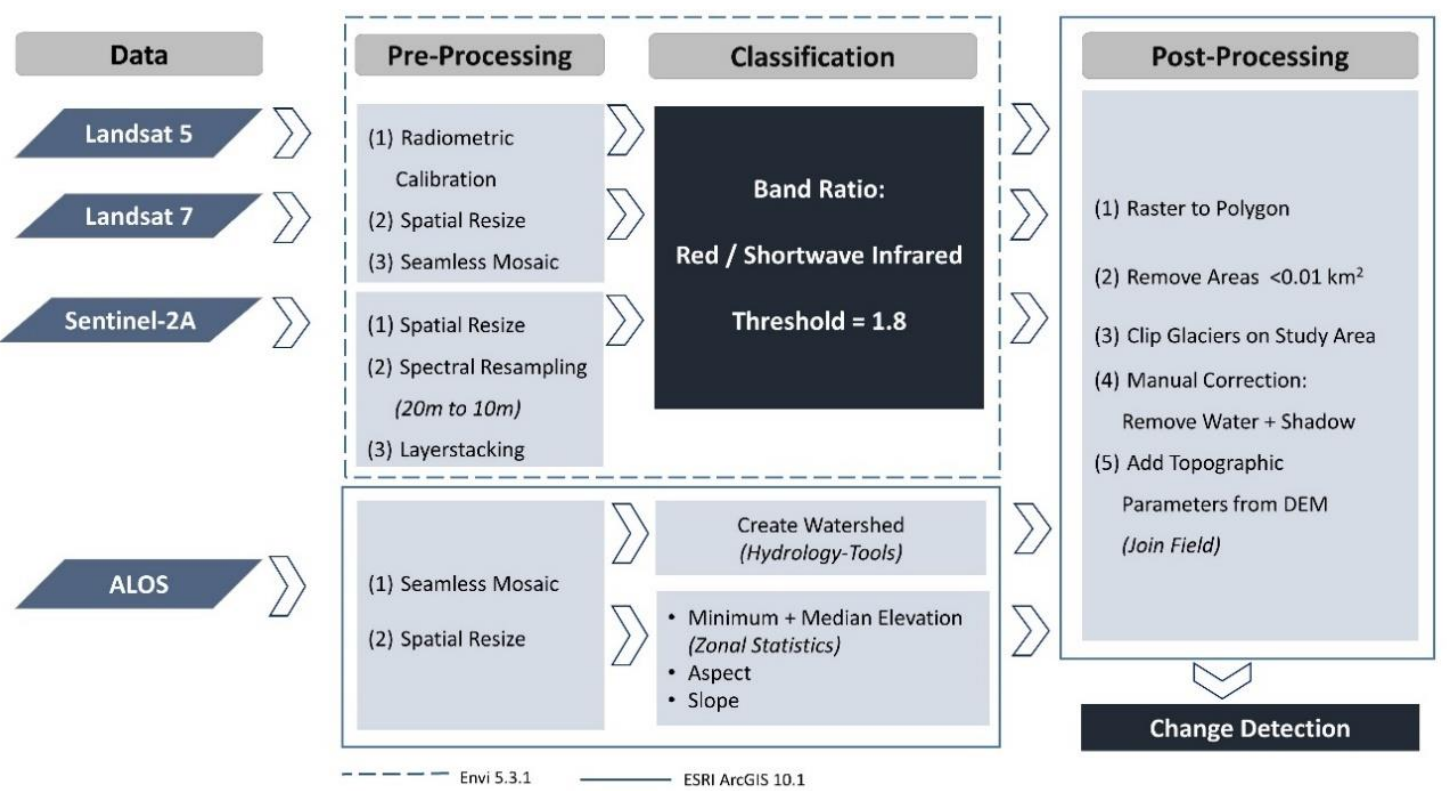

Figure 4. Workflow with all processing steps for the clean-ice glacier classification.

The watersheds of Huasco valley and its two tributaries, El Tránsito and El Carmen, were calculated with the Hydrology Tool in ESRI ArcGIS 10.1 using an ALOS DEM (Advanced Land Observation Satellite Digital Elevation Model) provided by JAXA (Japan Aerospace Exploration Agency) with a spatial resolution of $30 \mathrm{~m}[54,55]$. In the Pascua Lama region, the watershed was manually corrected to include all glaciers along the pass, as also conducted by Rabatel et al. [23].

Table 1. Satellite data used in this study (VIS = visible, NIR = Near Infrared, SWIR = Short Wave Infrared). All scenes are captured by a descending orbit.

\begin{tabular}{|c|c|c|c|}
\hline Satellite Type & Acquisition Date & Scene ID & $\begin{array}{l}\text { Spectral and Spatial Resolution } \\
\qquad(\mathrm{m} \times \mathrm{m})\end{array}$ \\
\hline \multirow{2}{*}{ Landsat $5^{1}$} & 17 March 1986 & LT05L1TP2330801986031720170218 & VIS, NIR, SWIR: \\
\hline & 31 March 2000 & LE07L1TP2330802000033120170212 & VIS, NIR, SWIR: \\
\hline Landsat $7^{1}$ & 31 March 2000 & LE07L1TP2330812000033120170212 & 30 \\
\hline Sentinel-2A ${ }^{2}$ & 5 March 2016 & $\begin{array}{l}\text { S2AOPERPRDMSIL1CPDMC20160308T17 } \\
\text { 3710R096V20160305T14431620160305T144316 }\end{array}$ & VIS, NIR: 10, SWIR: 20 \\
\hline
\end{tabular}

${ }^{1}$ Data downloaded from http://earthexplorer.usgs.gov [56]; all Landsat images were available in L1T; ${ }^{2}$ Data downloaded from https://scihub.copernicus.eu/dhus/\#/home [57].

To investigate the impact of the Pascua Lama mine and its infrastructure on glacier changes, the upper Huasco valley was divided into six subregions, according to clusters of neighboring glaciers. 
Only those glacier clusters covering an area of more than $0.5 \mathrm{~km}^{2}$ in 1986 were considered for further analyses. The glaciers in the vicinity of Pascua Lama were subdivided into two subregions, depending on their distance to the mine. The following subregions were identified from north to south: Laguna Grande, Valeriano N, Valeriano, Cholloy, Pascua Lama, Potrerillo.

\subsection{Glacier Classification}

A standardized semi-automatic threshold approach based on the red/shortwave infrared band ratio was applied to delineate glacier boundaries $[49,58]$, as ice and snow are characterized by a high reflection in visible light and high absorption in the shortwave infrared range. Additional manual corrections, in particular, for shadow and water surfaces, are commonly required, even though the band ratio method is relatively accurate and time-efficient in delineating clean ice [59]. The threshold for image segmentation varies from region to region and must be estimated for each image separately [60]. A higher threshold prevents a false classification by shadows or water surfaces, but it has the consequence that pixels in the glacier boundary area, which belong to the glacier, were not classified as glacier area. A lower threshold, on the other hand, requires labor-intensive visual interpretation and manual corrections. Even though the usually recommended threshold is 2.0 [61-63], for this study, a lower threshold of 1.8 was found to be more appropriate $[58,64]$.

For further analyses, the classified ice-covered areas were transformed into vector data [64]. For satellite data with a spatial resolution of $10-30 \mathrm{~m}$, the recommended minimum glacier size is $0.01 \mathrm{~km}^{2}$ [51]. Thus all smaller ice-bodies were removed from the dataset. Each glacier was visually checked, and misclassified pixels were corrected using the method proposed by Paul et al. [58]. The topographic parameters aspect, slope, and elevation were derived from the ALOS DEM in ESRI ArcGIS 10.1, as described in Gardent et al. [53]. Topographical changes over the entire period of 30 years were not investigated in more detail, as only one DEM was available; instead, a glacier inventory with topographic characteristics was drawn up for 2016. To detect the average elevation of glaciers and rock glaciers, the median elevation was computed. In the statistics, components of fragmented glaciers were considered as entities, whereas for the calculation of mean glacier changes, the components of the former entity were added up. For change detection analyses, the periods 1986-2000, 2000-2016, as well as 1986-2016, were considered.

Multi-temporal glacier interpretation with various satellite datasets reveals uncertainties due to the pixel size and co-registration of satellite data [62]. The uncertainty was estimated with a buffer of half a pixel size for each glacier, as suggested by Granshaw and Fountain [65] and applied in further studies $[66,67]$. Thus, the uncertainty was $\pm 15 \mathrm{~m}$ for Landsat and $\pm 10 \mathrm{~m}$ for Sentinel imagery, respectively. The uncertainty increases for small glaciers as small polygons contain relatively more edge pixels compared to large glaciers [67]. The error estimation was calculated by the standard deviation of the sum of the error term $[53,68]$.

\subsection{Rock Glacier Mapping}

Rock glaciers are distinguished from clean-ice glaciers by their proportion of debris, the thickness of the rubble, and the ice content [69]. A visual image interpretation of the Sentinel-2A scene (5 March 2016) was carried out to map rock glaciers. Unlike glaciers, which can be identified by spectral differences, the surface debris on rock glaciers has similar spectral properties as surrounding areas, and the detection of rock glaciers with remote sensing data is difficult [5,70]. Hence, the integration of topographic information is required for rock glacier delineation, as seen in [70]. To support the visual interpretation, topographic data, such as altitude, a hillshade image, slope angle, and curvature, from ALOS DEM [71] and a higher spatial resolution Microsoft Bing Map were loaded into ESRI ArcGIS 10.1 [26]. Although these satellite images have different acquisition dates, they are useful tools in visual image interpretation [58].

Rock glaciers are characterized by steep terminal fronts with high inclination angles between $35-45^{\circ}[12,72]$ and a relatively flat upper side. The steep fronts generate a narrow strip of light shadow 
on the southern part as the sunlight comes from the north. This results in darker colors along the rock glacier outline compared to the brighter flat upper surface and its surrounding. In contrast, north-oriented rock glaciers indicate bright colors on the steep terminal front and darker colors on the flat surface. This was also checked using the slope differences in the slope layer. Shading effects of the outlines were clearly visible in the hillshade layer and the satellite image as seen for three SE-oriented rock glaciers in the northern part of the study area (Figure 5).
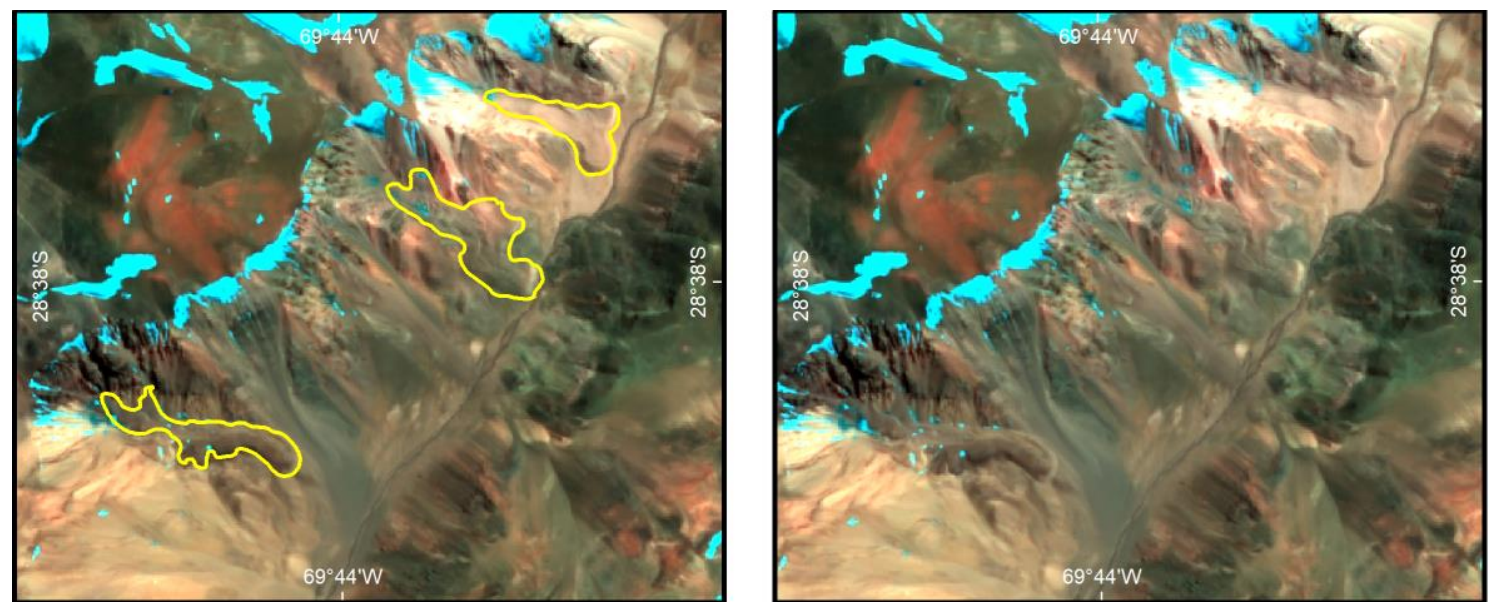

Figure 5. (Left) An example of three rock glacier delineations (yellow) in the north of Tránsito tributary; (Right) Shading effects of the outlines are visible. Background map: Sentinel-2A (5 March 2016), false color composite SWIR-NIR-Red.

However, the delineation in the upper part of the rock glaciers is difficult as no clear delineations are visible in satellite imagery $[58,59,72]$. Thus, the detected area can differ by about $100 \mathrm{~m}$ depending on the operator [58]. The upper edge of rock glaciers was delineated just below the funnel-shaped cirque or glacier fore field, assuming that this was the transition to non-moving terrain [8,72].

Distinguishing between active, inactive, and relict rock glaciers or water-saturated mass movements is challenging. Inactive and relict rock glaciers show lower inclinations at the front than active rock glaciers and, thus, often a softer contrast on satellite images [12,73]. In addition, the surface of active rock glaciers typically shows depressions, furrows, ridges, and lobes that are oriented transverse or longitudinal to the flow direction [74,75]. Features that showed neither a color contrast between the frontal slope and upper surface nor evidence of surface flow features were not included in the inventory [8]. In uncertain cases, a surface shape was not classified as a rock glacier. Consequently, a slight misclassification can be assumed. Topographic information (altitude, aspect, slope) was determined as described above for the glaciers and added to the rock glacier shapefile [53]. Rock glacier delineation by visual interpretation reaches its limit, as rock glaciers are likely to be located in shady niches rather than in sun-exposed areas. Thus, surface features were not visible in satellite imagery [12]. Due to the low spatial resolution of Landsat images and due to the lack of DEM with a high spatial resolution for 1986 and 2000, rock glaciers were excluded from change detection analyses.

\section{Results}

\subsection{Glacier Inventory}

The glaciers of the Huasco valley are clustered around the highest peaks and along the highest ridges. In total, 167 clean-ice glaciers larger than $0.01 \mathrm{~km}^{2}$ cover an area of $16.35 \pm 6.06 \mathrm{~km}^{2}$ in March 2016. Figure 6 shows the number $(6 \mathrm{a})$ and area $(6 \mathrm{~b})$ of these glaciers by size classes in the tributaries $\mathrm{El}$ Tránsito and El Carmen. The Tránsito tributary features 104 glaciers covering an area of $8.43 \pm 1.77 \mathrm{~km}^{2}$. The glaciers are clustered in five subregions along the main Andean range. Almost half of its ice-covered 
area $\left(3.86 \pm 0.71 \mathrm{~km}^{2}\right)$ is located in the northern Laguna Grande subregion. Pascua Lama, at the transition to the Carmen tributary, shows the second largest cluster of glaciers with a total area of $2.65 \pm 0.28 \mathrm{~km}^{2}$. In the Carmen tributary, 92\% of the glacier-covered area $\left(6.63 \pm 0.57 \mathrm{~km}^{2}\right)$ is located in the subregion Potrerillo in the southern vicinity of Pascua Lama. Only a few glaciers are located along the southernmost ridges.

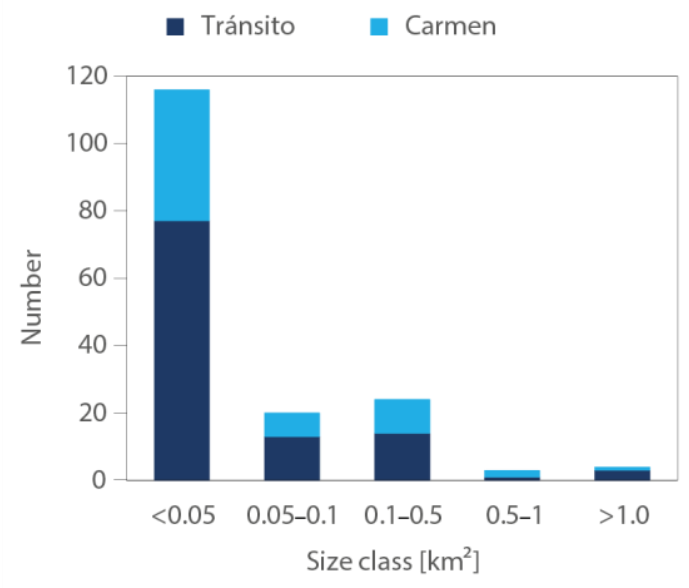

(a)

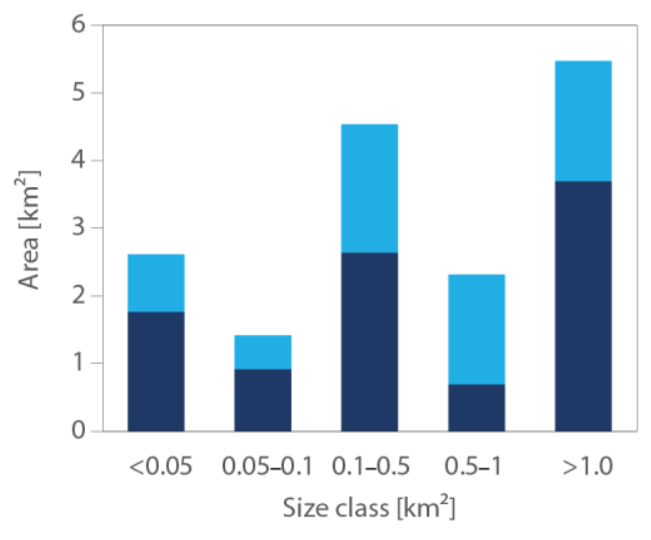

(b)

Figure 6. Area and number of glaciers by size class in the tributaries Carmen (light blue) and Tránsito (dark blue): (a) Number of glaciers by size class; (b) Area of glaciers in $\mathrm{km}^{2}$ by size class.

In the entire study area, $70 \%$ of the glaciers are smaller than $0.05 \mathrm{~km}^{2}$ and amounts $16 \%$ of the glacier-covered area; and the largest seven glaciers $>0.5 \mathrm{~km}^{2}$ account for $48 \%$ of the glacier-covered area. The Guanaco, the largest glacier of the study area, located in the Potrerillo subregion south of Pascua Lama, covers an area of $1.77 \pm 0.09 \mathrm{~km}^{2}$. The second-largest unnamed glacier $\left(1.74 \pm 0.17 \mathrm{~km}^{2}\right)$ is located in the subregion, Laguna Grande. The third and fourth largest glaciers, Estrecho $\left(1.23 \pm 0.1 \mathrm{~km}^{2}\right)$ and Los Amarillos (1.02 $\left.\pm 0.09 \mathrm{~km}^{2}\right)$ are situated in Pascua Lama, to the north of the mining site.

All clean-ice glaciers terminate above $4500 \mathrm{~m}$ and $50 \%$ even above $5100 \mathrm{~m}$ (Figures 7 and 8). Almost $65 \%$ of the glacier-covered area is located between $5000 \mathrm{~m}$ and $5300 \mathrm{~m}$, while the mean hypsometric glacier altitude in Carmen is $4980 \mathrm{~m}$, which is around $200 \mathrm{~m}$ lower than in Tránsito where it reaches $5180 \mathrm{~m}$. In Carmen, no glaciers exist above $5360 \mathrm{~m}$, while glaciers in Tránsito can be found in altitudes of almost $5850 \mathrm{~m}$. As Figure 8 depicts, the median elevation of clean-ice glaciers larger than $0.35 \mathrm{~km}^{2}$ is between $5050 \mathrm{~m}$ and $5270 \mathrm{~m}$. In contrast, glaciers $<0.1 \mathrm{~km}^{2}$ tend to scatter over a broad elevation range between $4570 \mathrm{~m}$ and $5700 \mathrm{~m}$. The elevational analyses of glacier occurrence in the subregions show no meridional trend. The glaciers in the subregion Pascua Lama are characterized by the highest mean minimum elevation of $5190 \mathrm{~m}$ and mean median elevation of $5280 \mathrm{~m}$, followed by the glaciers of Valeriano $\mathrm{N}$ at around $5170 \mathrm{~m}$ and $5260 \mathrm{~m}$, respectively. The lowest minimum and median elevations can be found at $4880 \mathrm{~m}$ and $4990 \mathrm{~m}$ in Cholloy.

The main orientation of the glaciers is southwards (Figure 9). This is particularly pronounced in Carmen, where about $86 \%$ of the clean-ice glaciers are located on S-facing slopes, and not even one glacier is situated on NW- to NE-facing slopes. In Tránsito, 35\% and 49\% of the clean-ice glaciers are on slopes oriented towards the SE and S, respectively. Only four north-facing glaciers exist, which are smaller than $0.05 \mathrm{~km}^{2}$ and located on relatively flat slopes above $5300 \mathrm{~m}$, with three of them even above $5500 \mathrm{~m}$. The mean slope angle and the scatter of the glaciers increase minimally towards smaller glaciers (Figure 9). The average slope angle is $25^{\circ}$, whereas the differences between both tributaries are neglectable. The slope angle of the glacier larger than $0.5 \mathrm{~km}^{2}$ ranges from $13^{\circ}$ to $25^{\circ}$, whereas the mean slope of glaciers smaller than $0.05 \mathrm{~km}^{2}$ varies between $2^{\circ}$ and $39^{\circ}$. 


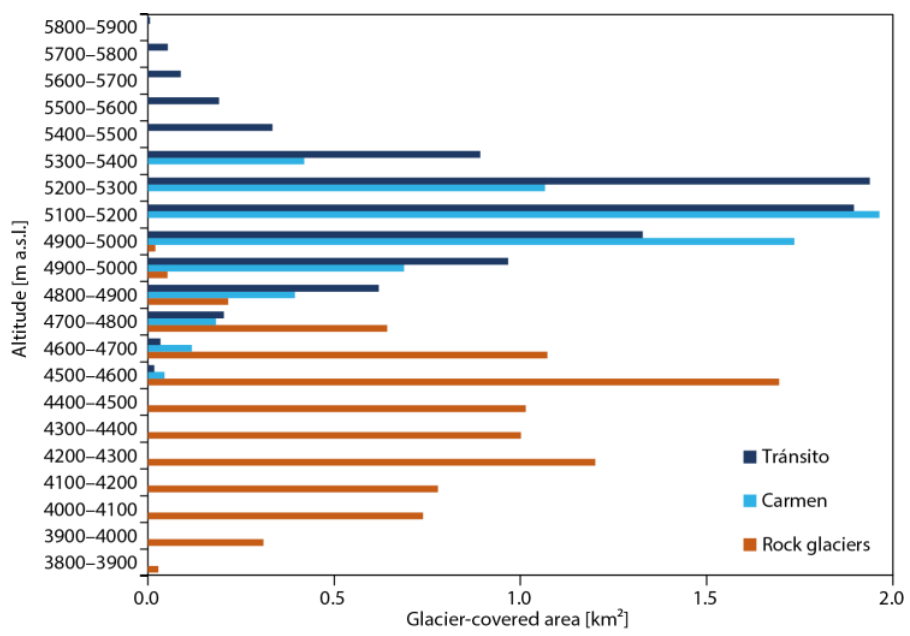

Figure 7. Hypsometric distribution of the glacier-covered area. The hypsometric distribution of glaciers in the tributaries of Carmen (light blue) and Tránsito (dark blue); rock glaciers in both tributaries (orange).
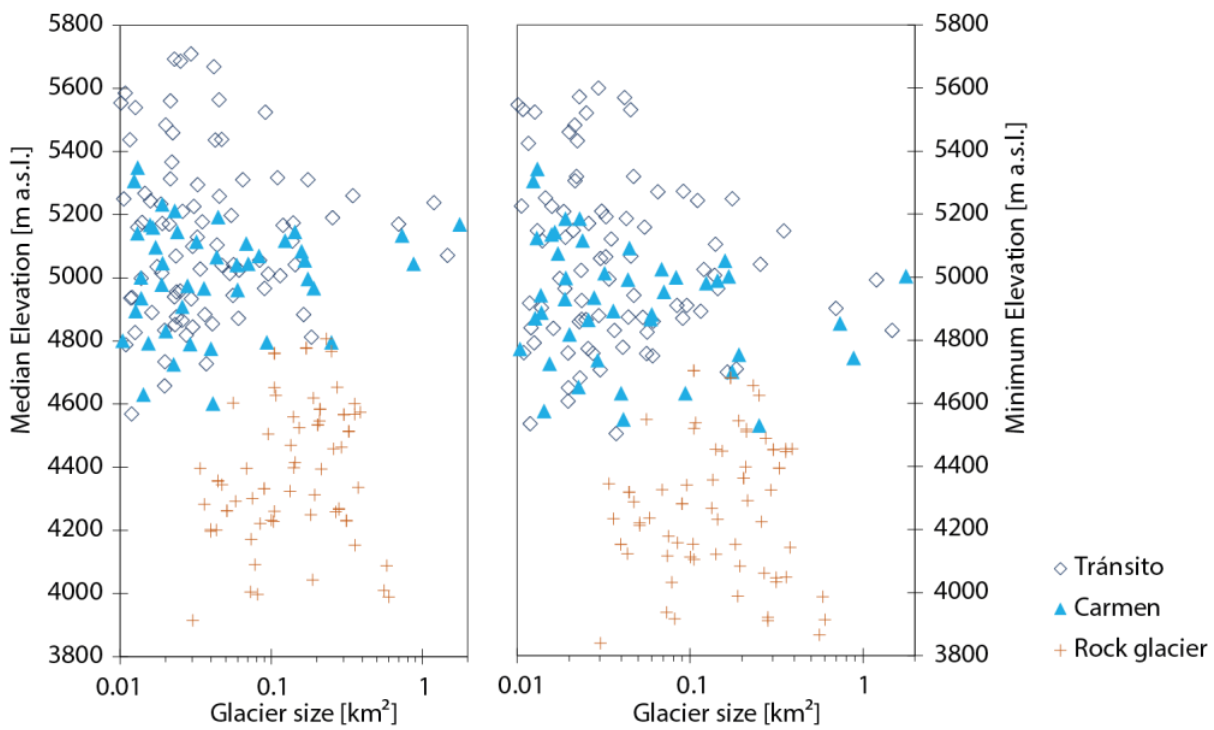

Figure 8. Area of clean-ice glaciers and rock glaciers in relation to (left) median elevation; (right) and to minimum elevation.

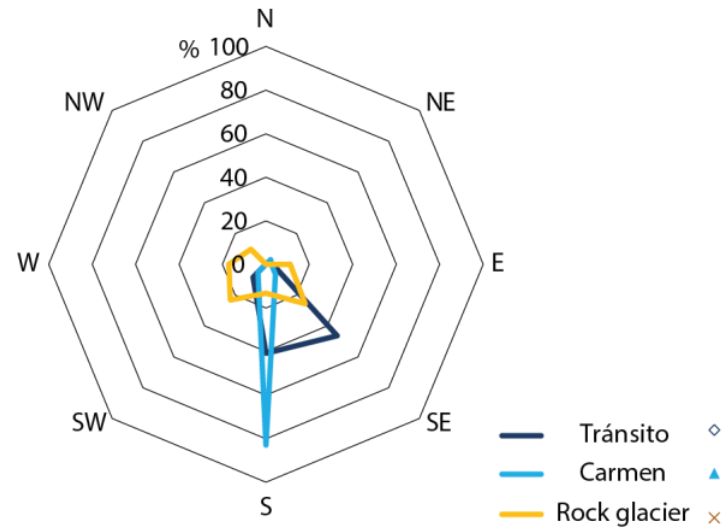

(a)

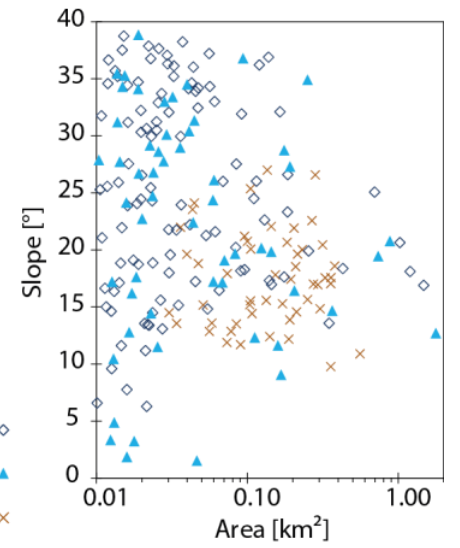

(b)

Figure 9. (a) Aspect and (b) mean slope angle of glaciers and rock glaciers. 
We identified 50 rock glaciers covering a total area of about $8.6 \mathrm{~km}^{2}$. Most of them are situated in Tránsito $(\mathrm{n}=42)$, covering an area of about $7.2 \mathrm{~km}^{2}$, while Carmen comprises in total only eight rock glaciers $\left(\sim 1.4 \mathrm{~km}^{2}\right)$. Due to the small number of rock glaciers in Carmen, no further distinction was conducted between both tributaries. The largest rock glacier covers an area of about $0.6 \mathrm{~km}^{2}$ and is located in Tránsito. Two-thirds $(\mathrm{n}=33)$ of the rock glaciers have a size between $0.1-0.5 \mathrm{~km}^{2}$, nine between $0.05-0.1 \mathrm{~km}^{2}$ (total area $0.7 \mathrm{~km}^{2}$ ), and seven are smaller than $0.05 \mathrm{~km}^{2}$ (total area $0.3 \mathrm{~km}^{2}$ ). Compared to clean-ice glaciers, rock glaciers are located at lower altitudes ranging from $3840 \mathrm{~m}$ to $5070 \mathrm{~m}$ and with a mean elevation of $4420 \mathrm{~m}$ and on lower angled slopes ranging from $10^{\circ}$ to $27^{\circ}$ with an average of $18^{\circ}$. Most of them are located on SE- to SW-facing slopes.

\subsection{Glacier Changes}

The glacier-covered area decreased from $26.11 \pm 5.35 \mathrm{~km}^{2}$ in 1986 to $24.99 \pm 5.15 \mathrm{~km}^{2}$ in 2000 and $16.35 \pm 6.06 \mathrm{~km}^{2}$ in 2016 (Table 2), displaying a relative ice-cover loss of $39 \%\left(1.3 \% \mathrm{a}^{-1}\right)$. Due to glacier shrinkage, several glaciers have been fragmented into two or more parts. Thus, the number of glaciers grew from 162 to 167, despite the disappearance of 30 glaciers-19 of them disappeared between 1986 and 2000. Because of glacier shrinkage, the number of glaciers in the size class $<0.05 \mathrm{~km}^{2}$ grew from 77 to 116 , and its ice-covered area increased from $1.93 \pm 1.02 \mathrm{~km}^{2}$ to $2.61 \pm 1.11 \mathrm{~km}^{2}$ between 1986 and 2016 (Table 2). All other size classes are characterized by a decrease ranging from $16 \%$ to $54 \%$.

The subregional analysis (Figure 10) indicates that in Laguna Grande and Valeriano N, the glacier-covered area was almost stable $(-2 \%)$ or slightly increased $(7 \%)$. However, five glaciers-four of them belong to the size class $<0.05 \mathrm{~km}^{2}$ and one to size class $0.05-0.1 \mathrm{~km}^{2}$-disappeared. Glaciers $<0.05 \mathrm{~km}^{2}$ were characterized by an average increase of about $20 \%$ and $26 \%$. However, the two glaciers $>1 \mathrm{~km}^{2}$ were stable between 1986 and 2000. In Valeriano, the glacier-covered area decreased by about $8 \%\left(1.85 \pm 0.61 \mathrm{~km}^{2}\right.$ to $\left.1.70 \pm 0.62 \mathrm{~km}^{2}\right)$, and glaciers $<0.05 \mathrm{~km}^{2}$ lost $26 \%$ on average of their surface. In Cholloy, the glacier cover was almost stable, and in the southernmost subregion Potrerillo, a slight decrease of about $4 \%\left(9.17 \pm 1.61 \mathrm{~km}^{2}\right.$ to $\left.8.76 \pm 1.52 \mathrm{~km}^{2}\right)$ was detectable, whereas three glaciers $<0.05 \mathrm{~km}^{2}$ disappeared. With an average relative decrease of $2 \%$, the three glaciers $>1 \mathrm{~km}^{2}$ - Guanaco, Canito, Ortigas 1, were almost stable. Contrary to this, in the surrounding of the Pascua Lama mine, the glaciers were characterized by a comparable high shrinkage rate. In this subregion, the glacier-covered area decreased from $4.43 \pm 0.67 \mathrm{~km}^{2}$ to $3.72 \pm 0.53 \mathrm{~km}^{2}$ by about $16 \%$. The two largest glaciers of Pascua Lama showed a diverse retreat pattern. Contrary to Los Amarillos $\left(1.25 \mathrm{~km}^{2} \pm 0.13 \mathrm{~km}^{2}\right)$, that was almost stable, the Estrecho indicated a decrease by about $11 \%\left(1.75 \pm 0.17 \mathrm{~km}^{2}\right.$ to $\left.1.56 \pm 0.15 \mathrm{~km}^{2}\right)$. Furthermore, a comparable high mean relative decrease was detectable for the glaciers of the size classes $0.1-0.5 \mathrm{~km}^{2}$ and $<0.05 \mathrm{~km}^{2}$, with about $39 \%\left(2.8 \% \mathrm{a}^{-1}\right)$ and $62 \%\left(4.4 \% \mathrm{a}^{-1}\right)$, respectively. Three glaciers belonging to the size class $<0.05 \mathrm{~km}^{2}$ disappeared during this observation period.

Between 1986 and 2000, only a slight glacier decrease of about $2 \%\left(0.1 \% \mathrm{a}^{-1}\right)$ was detectable for the entire study area that is within the range of uncertainty. Taking into account changes in individual ice-bodies, then the glaciers of size class $0.1-0.5 \mathrm{~km}^{2}$ showed the highest mean decrease by about $8 \%$, whereas glaciers larger than $0.5 \mathrm{~km}^{2}$ shrunk by $2 \%$ on average. Despite the small decreasing rate, 19 glaciers disappeared during this observation period (Figure 11). 
Table 2. Number of glaciers $(\mathrm{N})$, glacier-covered area $\left(\mathrm{km}^{2}\right)$ in total and by size class in the study area and the tributaries Tránsito and Carmen are listed for the three observation periods 1986, 2000, and 2016; absolute and relative changes in the total glacier-covered area and mean average glacier decrease per size class between 1986-2000, 1986-2016, 2000-2016 are given.

\begin{tabular}{|c|c|c|c|c|c|c|c|c|c|c|c|c|c|c|c|c|c|c|c|}
\hline & & \multicolumn{3}{|c|}{1986} & \multicolumn{3}{|c|}{2000} & \multicolumn{3}{|c|}{$2000-1986$} & \multicolumn{3}{|c|}{2016} & \multicolumn{3}{|c|}{ 2016-1986 } & \multicolumn{3}{|c|}{ 2016-2000 } \\
\hline & & $\mathbf{N}$ & $\mathrm{km}^{2}$ & $(\%)$ & $\mathbf{N}$ & $\left(\mathrm{km}^{2}\right)$ & $(\%)$ & $\left(\mathrm{km}^{2}\right)$ & $(\%)$ & $\left(\% a^{-1}\right)$ & $\mathbf{N}$ & $\left(\mathrm{km}^{2}\right)$ & $(\%)$ & $\left(\mathrm{km}^{2}\right)$ & $(\%)$ & $\left(\% \mathrm{a}^{-1}\right)$ & $\left(\mathrm{km}^{2}\right)$ & $(\%)$ & $\left(\% \mathrm{a}^{-1}\right)$ \\
\hline \multirow{7}{*}{$\begin{array}{l}\text { total glacier- } \\
\text { covered area }\end{array}$} & total & 162 & $26.11 \pm 5.35$ & 100.0 & 152 & $24.99 \pm 5.15$ & 100.0 & \multirow[t]{6}{*}{-1.12} & -2.0 & -0.1 & 167 & $16.35 \pm 3.06$ & 100.0 & \multirow[t]{6}{*}{-9.76} & -38.5 & -1.3 & \multirow[t]{6}{*}{-8.64} & -35.6 & -2.2 \\
\hline & $>1$ & 7 & $10.91 \pm 1.07$ & 41.8 & 7 & $10.69 \pm 1.06$ & 42.8 & & -2.3 & -0.2 & 4 & $5.47 \pm 0.4$ & 33.5 & & -49.9 & -1.7 & & -48.8 & -3.1 \\
\hline & $0.5-1.0$ & 4 & $2.77 \pm 0.41$ & 10.6 & 4 & $2.71 \pm 0.41$ & 10.8 & & -8.2 & -0.6 & 3 & $2.31 \pm 0.21$ & 14.1 & & -16.5 & -0.5 & & -14.5 & -0.9 \\
\hline & $0.1-0.5$ & 41 & $8.06 \pm 1.98$ & 30.9 & 39 & $7.4 \pm 1.8$ & 29.6 & & -4.8 & -0.3 & 24 & $4.54 \pm 0.92$ & 27.7 & & -43.8 & -1.5 & & -38.7 & -2.4 \\
\hline & $0.05-0.1$ & 33 & $2.44 \pm 0.87$ & 9.3 & 32 & $2.32 \pm 0.85$ & 9.3 & & -3.0 & -0.2 & 20 & $1.42 \pm 0.43$ & 8.7 & & -41.9 & -1.4 & & -39.0 & -2.4 \\
\hline & $<0.05$ & 77 & $1.93 \pm 1.02$ & 7.4 & 72 & $1.87 \pm 1.01$ & 7.5 & & -2.0 & -0.1 & 116 & $2.61 \pm 1.11$ & 16.0 & & 35.8 & 1.2 & & 40.0 & 2.5 \\
\hline & total & 104 & $15.3 \pm 3.34$ & 59.9 & 101 & $13.86 \pm 3.15$ & 61.4 & \multirow[t]{6}{*}{-1.44} & -1.8 & -0.1 & 106 & $9.64 \pm 1.89$ & 59.0 & \multirow[t]{6}{*}{-5.66} & -37.4 & -1.2 & \multirow[t]{6}{*}{-4.22} & -34.6 & -2.2 \\
\hline \multirow{5}{*}{ Tránsito } & $>1$ & 4 & $6.56 \pm 0.67$ & 25.1 & 4 & $5.18 \pm 0.53$ & 25.7 & & -2.1 & -0.1 & 3 & $2.67 \pm 0.21$ & 22.6 & & -38.3 & -1.3 & & -37.2 & -2.3 \\
\hline & $0.5-1.0$ & 3 & $1.83 \pm 0.33$ & 7.0 & 3 & $1.83 \pm 0.33$ & 7.3 & & -0.2 & 0.0 & 1 & $0.70 \pm 0.09$ & 4.3 & & -43.6 & -1.5 & & -42.4 & -2.6 \\
\hline & $0.1-0.5$ & 22 & $4.31 \pm 1.08$ & 16.5 & 25 & $4.31 \pm 1.08$ & 18.1 & & 5.3 & 0.4 & 14 & $2.64 \pm 0.51$ & 16.1 & & -61.9 & -2.1 & & -61.8 & -3.9 \\
\hline & $0.05-0.1$ & 24 & $1.74 \pm 0.60$ & 6.7 & 17 & $1.20 \pm 0.44$ & 4.8 & & -31.2 & -2.2 & 12 & $0.85 \pm 0.27$ & 5.2 & & -38.7 & -1.3 & & -41.8 & -2.6 \\
\hline & $<0.05$ & 51 & $1.19 \pm 0.65$ & 4.6 & 52 & $1.37 \pm 0.75$ & 5.5 & & 14.7 & 1.1 & 76 & $1.75 \pm 0.72$ & 10.7 & & -51.0 & -1.7 & & -28.8 & -1.8 \\
\hline \multirow{6}{*}{ Carmen } & total & 58 & $10.48 \pm 1.40$ & 40.1 & 53 & $9.64 \pm 1.82$ & 38.6 & \multirow[t]{6}{*}{-0.84} & -8.0 & -0.6 & 59 & $6.63 \pm 0.57$ & 40.5 & \multirow[t]{6}{*}{-3.85} & 46.5 & 1.6 & \multirow[t]{6}{*}{-3.01} & 27.7 & 1.7 \\
\hline & $>1$ & 3 & $4.36 \pm 0.40$ & 16.7 & 3 & $4.27 \pm 0.41$ & 17.1 & & -2.0 & -0.1 & 1 & $1.77 \pm 1.00$ & 10.8 & & -36.8 & -1.2 & & -31.3 & -2.0 \\
\hline & $0.5-1.0$ & 1 & $0.94 \pm 0.08$ & 3.6 & 1 & $0.88 \pm 0.08$ & 3.5 & & -6.3 & -0.4 & 2 & $1.62 \pm 0.11$ & 9.9 & & -59.3 & -2.0 & & -58.5 & -3.7 \\
\hline & $0.1-0.5$ & 19 & $3.76 \pm 0.89$ & 14.4 & 14 & $2.87 \pm 0.66$ & 11.5 & & -23.7 & -1.7 & 10 & $1.90 \pm 0.41$ & 11.6 & & 72.1 & 2.4 & & 83.7 & 5.2 \\
\hline & $0.05-0.1$ & 9 & $0.70 \pm 0.27$ & 2.7 & 15 & $1.12 \pm 0.41$ & 4.5 & & 61.0 & 4.4 & 7 & $0.49 \pm 0.15$ & 3.0 & & -49.6 & -1.7 & & -33.9 & -2.1 \\
\hline & $<0.05$ & 26 & $0.73 \pm 0.37$ & 2.8 & 20 & $0.50 \pm 0.26$ & 2.0 & & -32.0 & -2.3 & 39 & $0.85 \pm 0.38$ & 5.2 & & -29.1 & -1.0 & & -55.9 & -3.5 \\
\hline
\end{tabular}




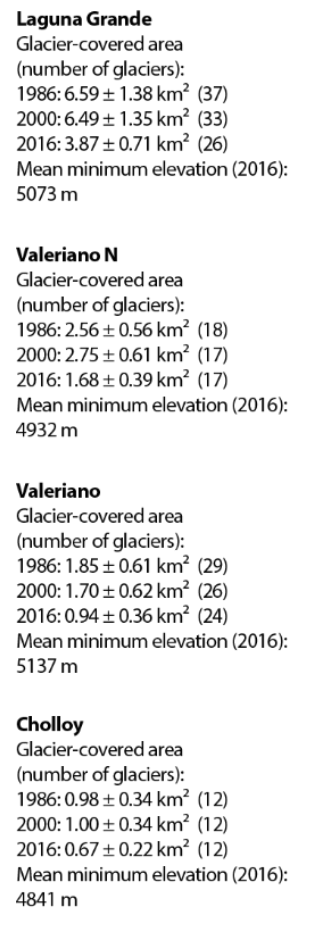

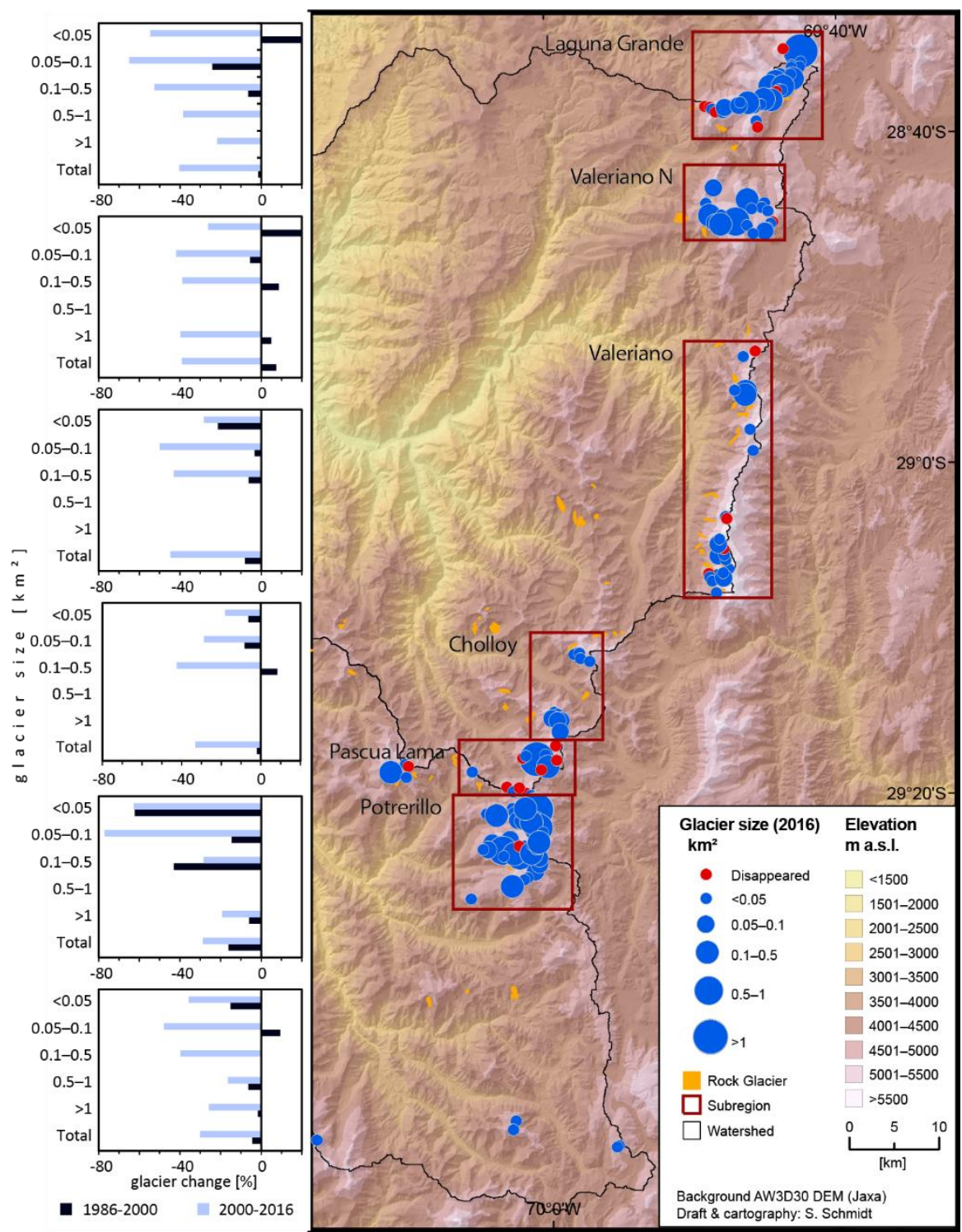

Figure 10. Glacier distribution (2016) and glacier changes in the six subregions from 1986 to 2000 and 2000 to 2016.

Between 2000 and 2016, the shrinkage of the total glacier-covered area in Huasco valley increased to $36 \%\left(2.2 \% \mathrm{a}^{-1}\right)$. In all subregions, a shrinkage was detectable varying between $29 \%\left(1.8 \% \mathrm{a}^{-1}\right)$ in Pascua Lama and 30\% $\left(1.9 \% \mathrm{a}^{-1}\right)$ in Potrerillo, to $45 \%\left(2.8 \% \mathrm{a}^{-1}\right)$ in Valeriano. In this second observation period, 13 glaciers disappeared; most of them belonged to the size class $<0.05 \mathrm{~km}^{2}$. But even Toro 2 belonging to glacier size class $0.1-0.5 \mathrm{~km}^{2}$ in 1986 vanished between 2000 and 2016; its area decreased from $0.29 \pm 0.07 \mathrm{~km}^{2}$ in 1986 to $0.09 \pm 0.04 \mathrm{~km}^{2}$ in 2000 before its disappearance. In general, glaciers of the size class $0.05-0.1 \mathrm{~km}^{2}$ were characterized by the highest mean area loss by more than 50\%. However, in Pascua Lama, this size class showed the highest average retreating rate of $77 \%$; additionally, glaciers $<0.05 \mathrm{~km}^{2}$ indicated an average retreat of about $63 \%$. Only in Laguna Grande, the glaciers of this size class showed similar high shrinkage rates of about $55 \%$. Furthermore, compared to 1986-2000, glaciers $>1 \mathrm{~km}^{2}$ were characterized by a high average decrease of about $25 \%$; Canito lost almost 50\% of its area, and the unnamed glacier in Valeriano N 40\%, whereas Guanco decreased only by about $14 \%$. 


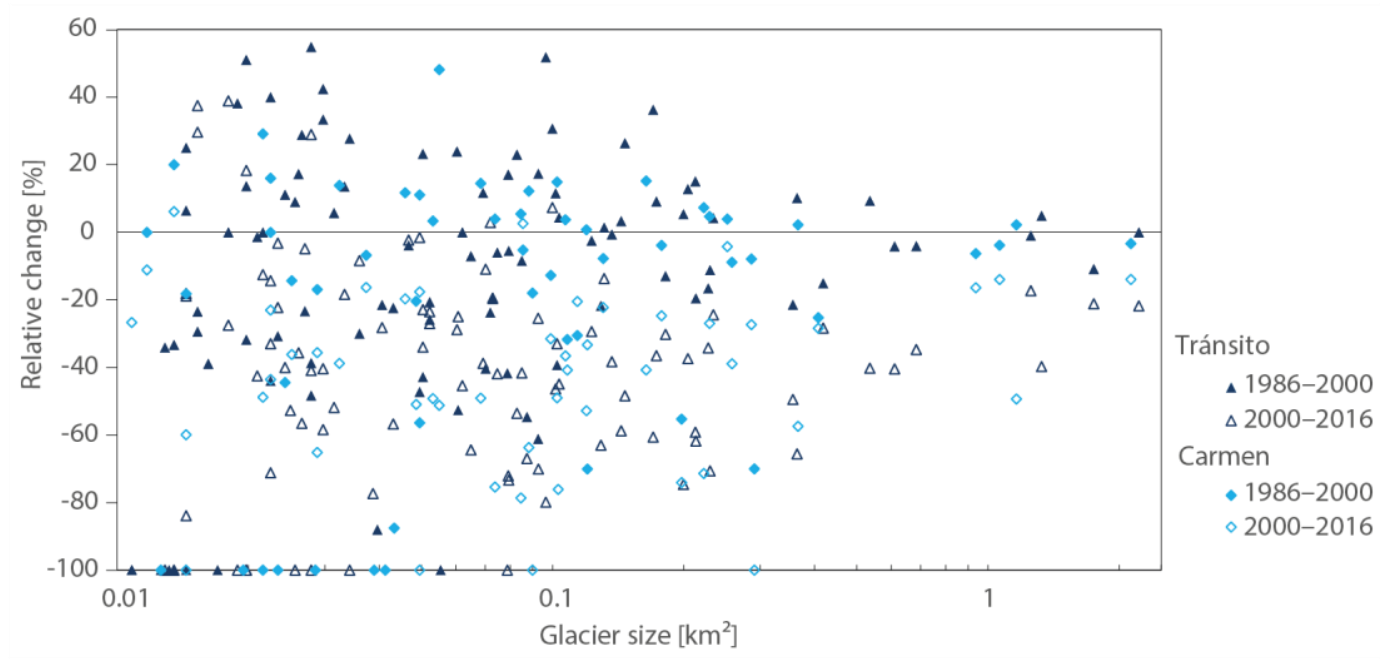

Figure 11. Relative glacier changes from 1986 to 2000 (points) and 2000 to 2016 (triangles). Some outliers $(>60 \%)$ are outside the $y$-axis and are not shown.

\section{Discussion}

\subsection{Glacier and Rock Glacier Inventory from 2016}

Clean-ice glaciers and rock glaciers are the predominant cryospheric features in the upper Huasco valley, while debris-covered glaciers were not detectable, as also shown in other studies $[8,23,76]$. The glaciers are very small, and their large scatter in median elevation implies that climatic conditions and topography determine their distribution. Shadowing effects are significant for the predominant location of glaciers and rock glaciers on south-facing slopes [23,77]. Aeolian redistribution of snow is another important factor, as snow accumulates on leeward slopes and ridges or topographic depressions [8,23]. According to Gascoin et al. [78], glaciers in the Huasco valley receive positive rates of drifting snow, which can reduce the glacier melt even in dry years.

Fifty rock glaciers with an area of about $8.6 \mathrm{~km}^{2}$ were detected in 2016 , similar to investigations by Nicholson et al. [8], who mapped 40 rock glaciers covering an area of $6.30 \mathrm{~km}^{2}$ in 2004 . In both studies, the numbers of identified rock glaciers were significantly smaller compared to the inventory by Azòcar et al. [26], who mapped more than 400 rock glaciers. Due to the lack of distinct spectral signatures, rock glacier mapping using remote sensing data needs to be based on visual interpretation and on-screen mapping. Depending on the spatial resolution of satellite data, the inclusion of topographic parameters, illumination conditions, as well as typology of active or inactive rock glaciers, as well as solifluction lobes, the numbers can differ.

\subsection{Glacier Change 1986-2016}

Despite the general importance of glacier melt in arid regions and the ongoing debate on the impact of mining infrastructures on glacier changes, detailed change analysis for the entire Huasco valley does not exist with the exception of a few glacier inventories. It is impossible to compare them as glaciers $<0.1 \mathrm{~km}^{2}$ have not been mapped in all studies [68]. Moreover, glaciers located in Pascua Lama are completely or only partly considered [23,29]; and sometimes their integration is unclear [8]. Furthermore, on-screen glacier mapping, as conducted by Nicholson et al. [8], tends to neglect some small glaciers [50], which are included in semi-automatic approaches, and, therefore, an underestimation of the ice-covered area can be assumed. Finally, seasonal snow cover patches on satellite images influence the results, for example, Barcaza et al. [24] identified 334 glaciers based on satellite data from January 2003.

For the presented glacier change analyses, satellite imagery with a spatial resolution of $20 \mathrm{~m}$ and $30 \mathrm{~m}$ was used. According to Paul et al. [51], a spatial resolution of $25 \mathrm{~m}$ or coarser is applicable for 
compact glaciers larger than $0.1 \mathrm{~km}^{2}$; hereafter, Landsat data reach their limitation. The relative impact of uncertainties increases with decreasing glacier size. Nevertheless, glaciers smaller than $0.1 \mathrm{~km}^{2}$ need to be included due to their direct response to climate change, particularly in regions where climate records or climate proxies are absent $[50,64]$. Due to their high area-to-volume ratio, they show a higher relative reduction than larger glaciers $[8,23,64,77]$, and due to their small perimeter-to-area ratio, they are more sensitive to radiation from the surrounding terrain [53].

Coinciding with the observed increase of glaciers in Central Andes in the 1980s and the first decade of the 21st century [79], the glaciers of Huasco valley were almost stable between 1986 and 2000. Since 2010, a strongly negative mass balance was measured in the Dry Andes [80], which was also displayed in the glacier decrease by about $36 \%$ in the study area between 2000 and 2016. Compared to the Olivares Alfa glacier complex ( $33^{\circ} \mathrm{S}$ ), where the glaciers shrunk by about $16 \%$ between 1989 and 2014 [81] and the Aconcagua Basin with a glacier decreased by about 33\% between 1986 and 2015 [82], the glacier decrease in Huasco valley was comparatively high.

Since glaciers in the upper Huasco valley are located at high altitudes, where the average annual temperature is expected to be as low as $-5^{\circ} \mathrm{C}$ [23], temperature increase plays a secondary role in glacier decrease. Rather, precipitation influences glacier changes $[23,80,83]$. Thus, the observed decrease could be associated with the severe drought event in central Chile (30-40 S) since 2010 [80,84]; within this period, Salas et al. [32] recorded minimum streamflow in the Santa Juana reservoir (see Figure 1). A changed Pacific Dipole Oscillation has caused a decadal decrease in precipitation by about $3.7 \mathrm{~mm}$ in central Chile since $1980[32,84]$. However, the impact of climate change on the formation of penitentes and their buffering effect on snowmelt is still unclear and needs to be evaluated further [85].

The subregional analysis indicated a more pronounced glacier decrease in Pascua Lama between 1986 and 2000, which was significantly higher than in the entire Huasco valley and could be explained solely by climate change, as concluded by Rabatel et al. [24], who observed an increased glacier decline between 1996 and 2007 compared to 1978 and 1996. However, besides climate change, human impacts on glacier decrease through mining activities can be assumed [1,42,44,83]. Mining activities can foster the melting of glaciers in different ways. Dust particle deposition and black carbon increase the albedo of glaciers $[42,44,86,87]$. As detectable in satellite imagery, massive road constructions started in the mid-1990s, leading to an increase in dust production and some roads even cross glaciers, such as Toro 2 . While mainly glaciers smaller than $0.05 \mathrm{~km}^{2}$ disappeared by 2016, the Toro 2 glacier, one of the glaciers which was planned to be "resettled", according to the first EIA, was the only glacier larger than $0.2 \mathrm{~km}^{2}$ in 1986 that disappeared completely by 2016. A particular environmental impact of mining activities on water resources, in general, and the cryosphere, in particular, can be assumed [88]. In the past, the Canadian mining company Barrick Gold had been fined for non-compliance with environmental regulations and irregularities in water management [41]. Despite the temporal stop of mining activities in 2013, satellite imagery revealed ongoing construction works and negotiation processes on the project still go on [41]. The complex issues of mining and mineral extraction in glacier-covered watersheds need to be considered in a broader and integrated socio-hydrological context [88] at the interface of environmental and developmental aspects, including glacio-fluvial dynamics, actor constellations, and regional socio-economic trajectories.

\section{Conclusions}

This study analyzed cryosphere changes in the Andes of the Huasco valley based on a multi-temporal glacier inventory. Glaciers in the Huasco valley have declined since 1986 with an accelerated reduction since 2000. The subregional analysis of glacier change indicated a detectable impact of mining activities on glacier retreat. Detailed further analyses are needed to quantify and weigh the impacts of climate change and mineral extraction. Despite their small size, the relevance of glaciers and rock glaciers for water availability in arid areas may increase, and conflicts over water resources between different actors may rise in the future, as witnessed in the Huasco valley. 
Author Contributions: Conceptualization, K.H., S.S., M.N., C.Z., and J.D.; methodology, K.H. and S.S.; software, K.H.; validation, S.S.; formal analysis, K.H. and S.S.; data curation, S.S.; writing-original draft preparation, K.H.; writing-review and editing, S.S., M.N., C.Z., and J.D.; visualization, K.H. and S.S.; project administration, J.D.; funding acquisition, J.D. All authors have read and agreed to the published version of the manuscript.

Funding: This study was funded by the Heidelberg Center for the Environment (HCE) at Heidelberg University as part of the Junior Research Group "Environment and Health in Arid Regions" (D.801000/12.032 ZUK 49/2 5.3.1 HCE, grant holder: Juliane Dame). Publication was funded by the Department of Geography, South Asia Institute, Heidelberg University.

Acknowledgments: We would like to thank Johanna Höhl (Heidelberg Center Latin America) for continuous support. We would also like to express our gratitude to contact persons in the Huasco area. Many thanks to two anonymous reviewers who provided valuable comments on an earlier version of the manuscript. Ravi Baghel (Heidelberg University) helped to edit the final manuscript.

Conflicts of Interest: The authors declare no conflict of interest.

\section{References}

1. Hock, R.; Rasul, G.; Adler, C.; Cáceres, B.; Gruber, S.; Hirabayashi, Y.; Jackson, M.; Kääb, A.; Kang, S.; Kutuzov, S.; et al. High Mountain Areas. In IPCC Special Report on the Ocean and Cryosphere in a Changing Climate (SROCC); 2019; Available online: https://www.ipcc.ch/srocc/chapter/chapter-2/ (accessed on 27 October 2020).

2. Viviroli, D.; Dürr, H.H.; Messerli, B.; Meybeck, M.; Weingartner, R. Mountains of the world, water towers for humanity: Typology, mapping, and global significance. Water Resour. Res. 2007, 43, 1-13. [CrossRef]

3. Viviroli, D.; Kummu, M.; Meybeck, M.; Kallio, M.; Wada, Y. Increasing dependence of lowland populations on mountain water resources. Nat. Sustain. 2020. [CrossRef]

4. Valdés-Pineda, R.; Pizarro, R.; García-Chevesich, P.; Valdés, J.B.; Olivares, C.; Vera, M.; Balocchi, F.; Pérez, F.; Vallejos, C.; Fuentes, R.; et al. Water governance in Chile: Availability, management and climate change. J. Hydrol. 2014, 519, 2538-2567. [CrossRef]

5. Larraín, S. Glaciares chilenos: Reservas estratégicas de agua dulce. Ambiente y Desarro. 2007, 23, $28-35$.

6. Magrin, G.O.; Marengo, J.A.; Boulanger, J.-P.; Buckeridge, M.S.; Castellanos, E.; Proveda, G.; Scarano, F.R.; Vicuna, S. Central and South America. In Proceedings of the IPCC; 2014; pp. 1499-1566. Available online: https: //www.ipcc.ch/site/assets/uploads/2018/02/WGIIAR5-Chap27_FINAL.pdf (accessed on 27 October 2020).

7. Brenning, A. Geomorphological, hydrological and climatic significance of rock glaciers in the Andes of Central Chile (33-35 S). Permafr. Periglac. Process. 2005, 16, 231-240. [CrossRef]

8. Nicholson, L.; Marín, J.; Lopez, D.; Rabatel, A.; Bown, F.; Rivera, A. Glacier inventory of the upper Huasco valley, Norte Chico, Chile: Glacier characteristics, glacier change and comparison with central Chile. Ann. Glaciol. 2009, 50, 111-118. [CrossRef]

9. Schaffer, N.; MacDonell, S.; Réveillet, M.; Yáñez, E.; Valois, R. Rock glaciers as a water resource in a changing climate in the semiarid Chilean Andes. Region. Environ. Chang. 2019, 19, 1263-1279. [CrossRef]

10. Squeo, F.A.; Holmgren, M.; Jiménez, M.; Albán, L.; Reyes, J.; Gutiérrez, J.R. Tree establishment along an ENSO experimental gradient in the Atacama desert. J. Veg. Sci. 2007, 18, 195-202. [CrossRef]

11. Vuille, M.; Milana, J.-P. High-latitude forcing of regional aridification along the subtropical west coast of South America. Geophys. Res. Lett. 2007, 34, 1-6. [CrossRef]

12. Brenning, A. Climatic and Geomorphological Controls of Rock Glaciers in the Andes of Central Chile: Combining Statistical Modelling and Field Mapping. Ph.D. Thesis, Humboldt University, Berlin, Germany, 2005.

13. Rosenblüth, B.; Fuenzalida, H.A.; Aceituno, P. Recent temperature variations in Southern South America. Int. J. Climatol. 1997, 17, 67-85. [CrossRef]

14. Fiebig-Wittmaack, M.; Astudillo, O.; Wheaton, E.; Wittrock, V.; Perez, C.; Ibacache, A. Climatic trends and impact of climate change on agriculture in an arid Andean valley. Clim. Chang. 2012, 111, 819-833. [CrossRef]

15. Huss, M.; Hock, R. Global-scale hydrological response to future glacier mass loss. Nat. Clim. Chang. 2018, 8, 135-140. [CrossRef]

16. Urkidi, L. Movimientos anti-mineros: El caso de Pascua-Lama en Chile. Rev. Iberoam. Econ. Ecol. 2008, 8, 63-77.

17. Urkidi, L. A glocal environmental movement against gold mining: Pascua-Lama in Chile. Ecol. Econ. 2010, 70, 219-227. [CrossRef] 
18. Li, F. Engineering responsibility: Environmental Mitigation and the Limits of Commensuration in a Chilean Mining Project. Focaal J. Glob. Hist. Anthropol. 2011, 60, 61-73. [CrossRef]

19. Gascoin, S.; Kinnard, C.; Ponce, R.; Lhermitte, S.; MacDonell, S.; Rabatel, A. Glacier contribution to streamflow in two headwaters of the Huasco River, Dry Andes of Chile. Cryosphere 2011, 5, 1099-1113. [CrossRef]

20. Garín, C. Inventario de glaciares de los Andes Chilenos desde los $18^{\circ}$ a los $32^{\circ}$ de Latitud Sur. Rev. Geogr. Norte Gd. 1987, 14, 35-48.

21. Rivera, A.; Casassa, G.; Acuña, C.; Lange, H. Variaciones recientes de glaciares en Chile. Investig. Geogr. 2000, 29-60. [CrossRef]

22. Rivera, A.; Acuña, C.; Casassa, G.; Bown, F. Use of remotely sensed and field data to estimate the contribution of Chilean glaciers to eustatic sea-level rise. Ann. Glaciol. 2002, 34, 367-372. [CrossRef]

23. Rabatel, A.; Castebrunet, H.; Favier, V.; Nicholson, L.; Kinnard, C. Glacier changes in the Pascua-Lama region, Chilean Andes (29 S): Recent mass balance and 50 yr surface area variations. Cryosphere 2011, 5, 1029-1041. [CrossRef]

24. Barcaza, G.; Nussbaumer, S.U.; Tapia, G.; Valdés, J.; García, J.-L.; Videla, Y.; Albornoz, A.; Arias, V. Glacier inventory and recent glacier variations in the Andes of Chile, South America. Ann. Glaciol. 2017, 58, 166-180. [CrossRef]

25. Azócar, G.F.; Brenning, A. Hydrological and geomorphological significance of rock glaciers in the dry Andes,

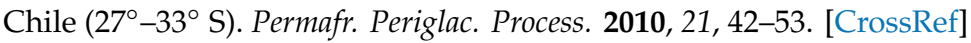

26. Azócar, G.F.; Brenning, A.; Bodin, X. Permafrost distribution modelling in the semi-arid Chilean Andes. Cryosphere 2017, 11, 877-890. [CrossRef]

27. Brenning, A.; Azócar, G.F. Statistical analysis of topographic and climatic controls and multispectral signatures

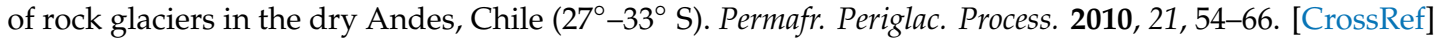

28. Brenning, A.; Peña, M.A.; Long, S.; Soliman, A. Thermal remote sensing of ice-debris landforms using ASTER: An example from the Chilean Andes. Cryosphere 2012, 6, 367-382. [CrossRef]

29. Kinnard, C.; Ginot, P.; Surazakov, A.; MacDonell, S.; Nicholson, L.; Patris, N.; Rabatel, A.; Rivera, A.; Squeo, F.A. Mass Balance and Climate History of a High-Altitude Glacier, Desert Andes of Chile. Front. Earth Sci. 2020, 8. [CrossRef]

30. MacDonell, S.; Kinnard, C.; Mölg, T.; Nicholson, L.; Abermann, J. Meteorological drivers of ablation processes on a cold glacier in the semi-arid Andes of Chile. Cryosphere 2013, 7, 1513-1526. [CrossRef]

31. Zang, C.; Dame, J.; Nüsser, M. Hydrochemical and environmental isotope analysis of groundwater and surface water in a dry mountain region in Northern Chile. Environ. Monit. Assess. 2018, 190, 1-19. [CrossRef] [PubMed]

32. Salas, I.; Herrera, C.; Luque, J.A.; Delgado, J.; Urrutia, J.; Jordan, T. Recent climatic events controlling the hydrological and the aquifer dynamics at arid areas: The case of Huasco River watershed, northern Chile. Sci. Total Environ. 2016, 571, 178-194. [CrossRef]

33. Kalthoff, N.; Bischoff-Gauß, I.; Fiebig-Wittmaack, M.; Fiedler, F.; Thürauf, J.; Novoa, E.; Pizarro, C.; Castillo, R.; Gallardo, L.; Rondanelli, R.; et al. Mesoscale Wind Regimes in Chile at 30 S. J. Appl. Meteor. 2002, 41, 953-970. [CrossRef]

34. Pizarro, R.; Vera, M.; Valdés, R.; Helwig, B.; Olivares, C. Multi-decadal variations in annual maximum peak flows in semi-arid and temperate regions of Chile. Hydrol. Sci. J. 2014, 59, 300-311. [CrossRef]

35. Fox, A.; Strecker, M. Pleistocene and modern snowlines in the Central Andes (24-28 S). Bamb. Geogr. Schr. 1991, 11, 169-182.

36. Zech, R.; Kull, C.; Veit, H. Late Quaternary glacial history in the Encierro Valley, northern Chile (29 S), deduced from 10Be surface exposure dating. Palaeogeogr. Palaeoclimatol. Palaeoeco. 2006, 234, 277-286. [CrossRef]

37. Montecinos, S.; Gutiérrez, J.R.; López-Cortés, F.; López, D. Climatic characteristics of the semi-arid Coquimbo Region in Chile. J. Arid Environ. 2016, 126, 7-11. [CrossRef]

38. BCN. Reportes Estadísticos Comunales 2015: Comuna Alto del Carmen. Available online: http: //reportescomunales.bcn.cl/2015/index.php/Alto_del_Carmen\#N.C3.BAmero_de_trabajadores_por_rama_ de_actividad_2009-2011-2013 (accessed on 17 July 2020).

39. Oficina de Estudios y Políticas Agrarias \& Centro de Información de Recursos Naturales. Principales Resultados Catastro Frutícola Región de Atacama. Resumen Nacional de la Superficie Frutícola. 2015. Available online: https://www.odepa.gob.cl/wp-content/uploads/2016/11/Atacama.pdf (accessed on 17 July 2020). 
40. Wagnitz, P.; Núñez, J.; Ribbe, L. Cost of environmental flow during water scarcity in the arid Huasco River basin, northern Chile. Hydrol. Sci. J. 2014, 59, 700-711. [CrossRef]

41. Li, F. Moving Glaciers: Remaking Nature and Mineral Extraction in Chile. Lat. Am. Perspect. 2018, 45, 102-119. [CrossRef]

42. Taillant, J.D. Glaciers. The Politics of Ice; Oxford University Press: New York, NY, USA, 2015; ISBN 9780199367252.

43. Haslam, P.A.; Godfrid, J. Activists and regulatory politics: Institutional opportunities, information, and the activation of environmental regulation. Extr. Ind. Soc. 2020, 7, 1077-1085. [CrossRef]

44. Brenning, A. The impact of mining on rock glaciers and glaciers: Examples from Central Chile. In Darkening Peaks; University of California Press: Berkeley, CA, USA, 2008; pp. 196-205.

45. Kronenberg, J. Global Warming, Glaciers and Gold Mining. In Proceedings of the 8th International Conference of the European Society for Ecological Economics, Ljubljana, Slovenia, 29 June-2 July 2009; Available online: https://pdfs.semanticscholar.org/cc37/a583048b8f1d4ce29804f918b42608e3a628.pdf (accessed on 27 October 2020).

46. French, A.; Barandiarán, J.; Rampini, C. Contextualizing conflict: Vital waters and competing values in glaciated environments. In The High-Mountain Cryosphere: Environmental Changes and Human Risks; Huggel, C., Carey, M., Clague, J.J., Kääb, A., Eds.; Cambridge University Press: Cambridge, UK, 2015; pp. 315-336. ISBN 978-1-107-06584-0.

47. Haslam, P.A. The Two Sides of Pascua Lama: Social Protest, Institutional Responses, and Feedback Loops. Eur. Rev. Lat. Am. Caribb. Stud. 2018, 106, 157-182. [CrossRef]

48. Pinto, J.; Prado, P.; Tirado-Alcaraz, J.A. Chile's Pascua Lama: Where Water Is worth More than Gold. In 2017-Environmental News in South America; Springer: Berlin, Germany, 2017; pp. 115-141.

49. Paul, F.; Bolch, T.; Kääb, A.; Nagler, T.; Nuth, C.; Scharrer, K.; Shepherd, A.; Strozzi, T.; Ticconi, F.; Bhambri, R.; et al. The glaciers climate change initiative: Methods for creating glacier area, elevation change and velocity products. Remote Sens. Environ. 2015, 162, 408-426. [CrossRef]

50. Paul, F.; Barry, R.G.; Cogley, J.G.; Frey, H.; Haeberli, W.; Ohmura, A.; Ommanney, C.; Raup, B.; Rivera, A.; Zemp, M. Recommendations for the compilation of glacier inventory data from digital sources. Ann. Glaciol. 2009, 50, 119-126. [CrossRef]

51. Paul, F.; Huggel, C.; Kääb, A.; Maisch, M. Comparison of TM-Derived Glacier Areas with Higher Resolution Data Sets. In EARSeL Workshop in Remote Sensing of Land Ice and Snow; 2003; pp. 15-21. Available online: http://eproceedings.uni-oldenburg.de/website/vol02_1/02_1_paul1.pdf (accessed on 27 October 2020).

52. ESA. Sentinel-2 Operations. Available online: http://www.esa.int/Our_Activities/Operations/Sentinel-2 operations (accessed on 17 July 2020).

53. Gardent, M.; Rabatel, A.; Dedieu, J.-P.; Deline, P. Multitemporal glacier inventory of the French Alps from the late 1960s to the late 2000s. Glob. Planet. Chang. 2014, 120, 24-37. [CrossRef]

54. Tadono, T.; Nagai, H.; Ishida, H.; Oda, F.; Naito, S.; Minakawa, K.; Iwamoto, H. Generation of the 30 m-mesh global digital surface model by ALOS PRISM. Int. Arch. Photogramm. Remote Sens. Spat. Inf. Sci. 2016, 41, 157-162. [CrossRef]

55. JAXA. ALOS Global Digital Surface Model “ALOS World 3D—30m” (AW3D30). Available online: http: //www.eorc.jaxa.jp/ALOS/en/aw3d30/index.htm (accessed on 17 July 2020).

56. USGS. Earthexplorer. Available online: https://earthexplorer.usgs.gov/ (accessed on 17 July 2020).

57. ESA. Sentinel-2. Available online: https://scihub.copernicus.eu/dhus/\#/home (accessed on 17 July 2020).

58. Paul, F.; Barrand, N.E.; Baumann, S.; Berthier, E.; Bolch, T.; Casey, K.; Frey, H.; Joshi, S.P.; Konovalov, V.; Le Bris, R.; et al. On the accuracy of glacier outlines derived from remote-sensing data. Ann. Glaciol. 2013, 54, 171-182. [CrossRef]

59. Racoviteanu, A.; Paul, F.; Raup, B.; Khalsa, S.; Armstrong, R. Challenges and recommendations in mapping of glacier parameters from space: Results of the 2008 Global Land Ice Measurements from Space (GLIMS) workshop, Boulder, Colorado, USA. Ann. Glaciol. 2009, 50, 53-69. [CrossRef]

60. Paul, F.; Kääb, A. Perspectives on the production of a glacier inventory from multispectral satellite data in the Canadian Arctic: Cumberland Peninsula, Baffin Island. Ann. Glaciol. 2005, 42, 59-66. [CrossRef]

61. Paul, F.; Huggel, C.; Kääb, A. Combining satellite multispectral image data and a digital elevation model for mapping debris-covered glaciers. Remote Sens. Environ. 2004, 89, 510-518. [CrossRef] 
62. Paul, F.; Winsvold, S.; Kääb, A.; Nagler, T.; Schwaizer, G. Glacier Remote Sensing Using Sentinel-2. Part II: Mapping Glacier Extents and Surface Facies, and Comparison to Landsat 8. Remote Sens. 2016, 8, 575. [CrossRef]

63. Pfeffer, W.T.; Arendt, A.A.; Bliss, A.; Bolch, T.; Cogley, J.G.; Gardner, A.S.; Hagen, J.-O.; Hock, R.; Kaser, G.; Kienholz, C.; et al. The Randolph Glacier Inventory: A globally complete inventory of glaciers. J. Glaciol. 2014, 60, 537-552. [CrossRef]

64. Schmidt, S.; Nüsser, M. Changes of High Altitude Glaciers from 1969 to 2010 in the Trans-Himalayan Kang Yatze Massif, Ladakh, Northwest India. Arct. Antarct. Alp. Res. 2012, 44, 107-121. [CrossRef]

65. Granshaw, F.D.; Fountain, A.G. Glacier change (1958-1998) in the North Cascades National Park Complex, Washington, USA. J. Glaciol. 2006, 52, 251-256. [CrossRef]

66. Bhambri, R.; Bolch, T.; Chaujar, R.K.; Kulshreshtha, S.C. Glacier changes in the Garhwal Himalaya, India, from 1968 to 2006 based on remote sensing. J. Glaciol. 2011, 57, 543-556. [CrossRef]

67. Bolch, T.; Menounos, B.; Wheate, R. Landsat-based inventory of glaciers in western Canada, 1985-2005. Remote Sens. Environ. 2010, 114, 127-137. [CrossRef]

68. Kamp, U.; Byrne, M.; Bolch, T. Glacier fluctuations between 1975 and 2008 in the Greater Himalaya Range of Zanskar, southern Ladakh. J. Mt. Sci. 2011, 8, 374-389. [CrossRef]

69. Janke, J.R.; Bellisario, A.C.; Ferrando, F.A. Classification of debris-covered glaciers and rock glaciers in the Andes of central Chile. Geomorphology 2015, 241, 98-121. [CrossRef]

70. Brenning, A. Benchmarking classifiers to optimally integrate terrain analysis and multispectral remote sensing in automatic rock glacier detection. Remote Sens. Environ. 2009, 113, 239-247. [CrossRef]

71. Müller, J.; Vieli, A.; Gärtner-Roer, I. Rock glaciers on the run-understanding rock glacier landform evolution and recent changes from numerical flow modeling. Cryosphere 2016, 10, 2865-2886. [CrossRef]

72. Roer, I.; Nyenhuis, M. Rockglacier activity studies on a regional scale: Comparison of geomorphological mapping and photogrammetric monitoring. Earth Surf. Process. Landf. 2007, 32, 1747-1758. [CrossRef]

73. Bodin, X.; Rojas, F.; Brenning, A. Status and evolution of the cryosphere in the Andes of Santiago (Chile, $33.5^{\circ}$ S.). Geomorphology 2010, 118, 453-464. [CrossRef]

74. Haeberli, W.; Hallet, B.; Arenson, L.; Elconin, R.; Humlum, O.; Kääb, A.; Kaufmann, V.; Ladanyi, B.; Matsuoka, N.; Springman, S.; et al. Permafrost creep and rock glacier dynamics. Permafr. Periglac. Process. 2006, 17, 189-214. [CrossRef]

75. Kääb, A. Permafrost and Periglacial Features: Rock Glaciers and Protalus Forms. In Encyclopedia of Quaternary Science, 2nd ed.; Mock, C.J., Elias, S.A., Eds.; Elsevier: Edinburgh, UK, 2013; pp. 535-541. ISBN 9780444536426.

76. Pellicciotti, F.; Ragettli, S.; Carenzo, M.; McPhee, J. Changes of glaciers in the Andes of Chile and priorities for future work. Sci. Total Environ. 2014, 493, 1197-1210. [CrossRef]

77. Paul, F.; Svoboda, F. A new glacier inventory on southern Baffin Island, Canada, from ASTER data: II. Data analysis, glacier change and applications. Ann. Glaciol. 2009, 50, 22-31. [CrossRef]

78. Gascoin, S.; Lhermitte, S.; Kinnard, C.; Bortels, K.; Liston, G.E. Wind effects on snow cover in Pascua-Lama, Dry Andes of Chile. Adv. Water Resour. 2013, 55, 25-39. [CrossRef]

79. Masiokas, M.H.; Christie, D.A.; Le Quesne, C.; Pitte, P.; Ruiz, L.; Villalba, R.; Luckman, B.H.; Berthier, E.; Nussbaumer, S.U.; González-Reyes, Á.; et al. Reconstructing the annual mass balance of the Echaurren Norte glacier (Central Andes, $33.5^{\circ} \mathrm{S}$ ) using local and regional hydroclimatic data. Cryosphere 2016, 10, 927-940. [CrossRef]

80. Dussaillant, I.; Berthier, E.; Brun, F.; Masiokas, M.; Hugonnet, R.; Favier, V.; Rabatel, A.; Pitte, P.; Ruiz, L. Two decades of glacier mass loss along the Andes. Nat. Geosci. 2019, 12, 802-808. [CrossRef]

81. Malmros, J.K.; Mernild, S.H.; Wilson, R.; Yde, J.C.; Fensholt, R. Glacier area changes in the central Chilean and Argentinean Andes 1955-2013/14. J. Glaciol. 2016, 62, 391-401. [CrossRef]

82. Ruiz Pereira, S.F.; Veettil, B.K. Glacier decline in the Central Andes ( $\left.33^{\circ} \mathrm{S}\right)$ : Context and magnitude from satellite and historical data. J. S. Am. Earth Sci. 2019, 94, 102249. [CrossRef]

83. Carrasco, J.F.; Casassa, G.; Quintana, J. Changes of the $0{ }^{\circ} \mathrm{C}$ isotherm and the equilibrium line altitude in central Chile during the last quarter of the 20th century/Changements de $l^{\prime}$ isotherme $0{ }^{\circ} \mathrm{C}$ et de la ligne d'équilibre des neiges dans le Chili central durant le dernier quart du 20ème siècle. Hydrol. Sci. J. 2005, 50, 661. [CrossRef] 
84. Boisier, J.P.; Rondanelli, R.; Garreaud, R.D.; Muñoz, F. Anthropogenic and natural contributions to the Southeast Pacific precipitation decline and recent megadrought in central Chile. Geophys. Res. Lett. 2016, 43, 413-421. [CrossRef]

85. Corripio, J.G.; Purves, R.S. Surface Energy Balance of High Altitude Glaciers in the Central Andes: The Effect of Snow Penitentes. In Climate and Hydrology in Mountain Areas; Jong, C.d., Collins, D., Ranzi, R., Eds.; Wiley: Hoboken, NJ, USA, 2010; pp. 15-27. ISBN 9780470858240.

86. Barandiarán, J. Documenting rubble to shift baselines: Environmental assessments and damaged glaciers in Chile. Environ. Plan. E 2020, 3, 58-75. [CrossRef]

87. Bellisario, A.; Ferrando, F.; Janke, J. Water resources in Chile: The critical relation between glaciers and mining for sustainable water management. Investig. Geogr. Chile 2013, 46, 3-24. [CrossRef]

88. Nüsser, M. Socio-hydrology: A New Perspective on Mountain Waterscapes at the Nexus of Natural and Social Processes. Mt. Res. Dev. 2017, 37, 518-520. [CrossRef]

Publisher's Note: MDPI stays neutral with regard to jurisdictional claims in published maps and institutional affiliations.

(C) 2020 by the authors. Licensee MDPI, Basel, Switzerland. This article is an open access article distributed under the terms and conditions of the Creative Commons Attribution (CC BY) license (http://creativecommons.org/licenses/by/4.0/). 